\title{
Gross Motor Skills Levels in Children with Autism Spectrum Disorder during the COVID-19 Pandemic
}

\author{
Diajeng Tyas Pinru Phytanza ${ }^{1}$, Erick Burhaein ${ }^{2, *}$, Ratko Pavlovic $^{3}$ \\ ${ }^{1}$ Department of Special Education, Faculty of Education, Universitas Negeri Yogyakarta, Yogyakarta 55281, Daerah Istimewa \\ Yogyakarta, Indonesia \\ ${ }^{2}$ Doctoral Program of Sports Education, School Postgraduates Studies, Universitas Pendidikan Indonesia, Bandung, 40154, Jawa Barat, \\ Indonesia \\ ${ }^{3}$ Faculty of Physical Education and Sport, University of East Sarajevo, Lukavica, 71126, East Sarajevo, Bosnia and Herzegovina
}

Received April 8, 2021; Revised May 11, 2021; Accepted June 20, 2021

\section{Cite This Paper in the following Citation Styles}

(a): [1] Diajeng Tyas Pinru Phytanza, Erick Burhaein, Ratko Pavlovic, "Gross Motor Skills Levels in Children with Autism Spectrum Disorder during the COVID-19 Pandemic," International Journal of Human Movement and Sports Sciences, Vol. 9, No. 4, pp. 738 - 745, 2021. DOI: 10.13189/saj.2021.090418.

(b): Diajeng Tyas Pinru Phytanza, Erick Burhaein, Ratko Pavlovic (2021). Gross Motor Skills Levels in Children with Autism Spectrum Disorder during the COVID-19 Pandemic. International Journal of Human Movement and Sports Sciences, 9(4), 738 - 745. DOI: 10.13189/saj.2021.090418.

Copyright $\odot 2021$ by authors, all rights reserved. Authors agree that this article remains permanently open access under the terms of the Creative Commons Attribution License 4.0 International License

\begin{abstract}
The purpose of this study was to determine the level of gross motor skills in ASD children during the COVID-19 Pandemic. Participants in this study were ASD children with a total of 25 children aged 8-12 years $(\mathrm{M}=$ 10.02; SD 1.27), who were selected by random sampling technique. This research instrument is the Test of Gross Motor Development-2 (TGMD-2). Data analysis in this study is descriptive analysis. The results of gross motor skills show that 20 ASD children are in the average standard score of 4-5 (gross motor question $=70-79)$ in the low assessment category $(80.00 \%)$ and 5 ASD children are in the average standard score of 1-3 (gross motor question $=<70)$ is included in the very low assessment category $(20.00 \%)$. Therefore, the majority of the total gross motoric data for ASD children are in the low category, namely 20 children or $80.00 \%$. This research is not without limitations in its implementation. This research contributes to the implementation of future research, namely the need for treatment to optimize Gross Motor skills in Children with Autism Spectrum Disorder during the COVID-19 Pandemic. The urgency for proper and measurable treatment and the limitations of this study are important things to pay attention to for further research.
\end{abstract}

Keywords Gross Motor, ASD, Age 8-12 Years, TGMD, COVID-19, Locomotor, Object Control

\section{Introduction}

The COVID-19 pandemic in various countries has made drastic changes in all activities, including sports. Adaptation to the changing circumstances during this pandemic was taken by the coaching team in a number of sports. The training program is packaged differently to adapt to conditions that are not ideal at this time, one of which is joint training using video conferencing services at each athlete's home [1], [2]. Training independently at home is also an option for some athletes in maintaining their performance.

Meanwhile, the existence of the COVID-19 pandemic is also a special sorrow for sports players who are struggling to improve athletes' performance and mobility. All sports competitions have stopped due to lock downs, large-scale social restrictions, or other terms that essentially limit the mobility of the population in a country [3], [4]. Athletes undergo independent isolation in the club provided by the club or in their respective homes. Even so, training with limited facilities at the mes or at home is still carried out intensively by them under the supervision of a team of coaches so that the standard target of training volume and fitness for daily athletes can be achieved.

During the COVID-19 pandemic, the volume of exercise is very important to pay attention to. A volume of 
exercise performed at high intensity over a long period of time weakens the immune system and increases the risk of infection of the inspiratory pathway even hours after exercise [5], [6]. While the recommended volume of light-moderate intensity exercise is beneficial for health and immune function, which is of course important to pay attention to during the COVID-19 pandemic [7].

The recommendation for children aged 5-17 years during the COVID-19 pandemic in various countries is to have 180 minutes of activity (training) per day. This recommended exercise volume is performed at a moderate exercise intensity. This of course takes into account the gender, height, weight, body fat, etc. of the athlete [8][10]. Then in training it cannot be separated from the most basic main element, namely movement of the athlete.

Movement is the main need for humans, most of human needs can be achieved through movement. For example, a student has to write, run, jump, jump, roll, and so on [11], [12]. Motor skills in children should be done at the earliest possible age, so that development and growth can be monitored properly. In addition, motor development in children is also a very important factor for the development of the individual as a whole. Children must interact more often with their surroundings through basic movements such as during growth and development at the age of five, namely crawling, walking, jumping, running [13], [14]. This period of growth and development is very important as a provision for children when they enter school age. At elementary school, children play games in physical education lessons and sports with the aim of finalizing basic movements [15], [16]. Elementary school age children are the embryo of the nation's successor. Therefore they need to be nurtured and developed so that in time they are not only capable of being motorbikes and innovators but also able to act as stabilizers in nation building.

Physical education and sports are media to encourage physical growth, psychological development, motor skills, knowledge and reasoning, appreciation of values (attitudes-mental-emotional-sports-spiritual-social), as well as habituation of healthy lifestyles which lead to stimulating growth and quality development. physical and psychological balance [17], [18]. At the primary school level, physical education and sports are aimed at maximizing all the abilities of the body components that exist in the student's body. The early period of elementary school is an age that is mature enough to develop basic motoric movements of children.

Characteristics of children with Autism Spectrum Disorder (ASD) of elementary school age basically have movements that may be almost the same as children in general [14], [19]. ASD children also have the opportunity to develop their basic motor skills, including locomotor, non-locomotor, and manipulative skills. Fundamental motor skills are a basis that must be learned and mastered by all humans. By having good basic movements, it can support all activities at a later age. Basic motion is very close to physical activity, all interdependent on one another. The occurrence of movement occurs because of the stimulation which is then channeled to the brain and digested then the movement is carried out or occurs. All these stages occur with the support of the cognitive or knowledge realm. Motor development is defined as "change in behavior over a lifetime and the processes that underlie a change".

Motor skills are defined as "Skills that involve large muscles, producing muscles from the trunk of the arms and legs" [20], [21]. Motor skills are the ability of a person to perform easy and difficult movements that involve various muscle actions. Motor skills are divided into two parts, namely fine and gross motor skills. Fine motor skills are skills that involve small muscles and do not require a lot of exertion. This movement includes writing, drawing, cutting, and so on, while gross motor skills are skills that involve large muscles such as the hands, feet, and all parts of the body and require strength. These movements include running, walking, jumping, throwing, kicking, and so on.

The COVID-19 condition that has hit the physical education process globally throughout the world [22]-[24], including problems with gross motor skills of ASD children. Based on the researchers' preliminary observations, it was known that during the COVID-19 pandemic, ASD children had a tendency to decrease gross motor skills [25]. This problem is what forms the basis for revealing it in research. The purpose of this study was to determine the level of gross motor skills in ASD children during the COVID-19 Pandemic.

Based on the urgency of this research, the following research question raises "What is the level of gross motor skills in ASD children during the COVID-19 Pandemic?".

\section{Materials and Methods}

\subsection{Research Method}

This research is an Ex Post Facto research, because the independent variables in this study are not controlled or specially treated but only reveal facts based on the measurement of the symptoms that have existed in the respondent before this research was carried out [26]. Ex post facto research, which means that the researcher wants to describe and explain a certain phenomenon or event whose results are objective, concrete, measurable, rational, and systematic by analyzing what factors influence it and providing a solution. Comparison of previous research and the recency of current research can see in table 1 . 
Table 1. Comparison of Previous Research and the Recency of Current Research

\begin{tabular}{|c|c|c|c|}
\hline No & Researcher (Year) & $\begin{array}{c}\text { Similarities of Previous Research - } \\
\text { New Research }\end{array}$ & $\begin{array}{l}\text { Recency and Originality } \\
\text { in New Research }\end{array}$ \\
\hline 1 & $\begin{array}{c}\text { Provost, et al (2007) } \\
{[27]}\end{array}$ & $\begin{array}{l}\text { Uncover the motor skills of ASD children. } \\
\text { Survey research methods. } \\
\text { Data collection techniques using tests and } \\
\text { measurements. }\end{array}$ & $\begin{array}{l}\text { 1. Conditions of the COVID-19 } \\
\text { Pandemic. } \\
\text { 2. Data collection followed health } \\
\text { protocols. } \\
\text { 3. The use of a newer instrument, the } \\
\text { TGMD-2. }\end{array}$ \\
\hline 2 & $\begin{array}{c}\text { Liu, et al (2014) } \\
{[28]}\end{array}$ & $\begin{array}{l}\text { 1. Uncover the motor skills of ASD children. } \\
\text { 2. Survey research methods. } \\
\text { 3. Data collection techniques using tests and } \\
\text { measurements. } \\
\text { 4. The use of a newer instrument, the TGMD-2. }\end{array}$ & $\begin{array}{l}\text { 1. Conditions of the COVID-19 } \\
\text { Pandemic. } \\
\text { Data collection followed health } \\
\text { protocols. }\end{array}$ \\
\hline 3 & $\begin{array}{l}\text { Pusponegoro, et al } \\
\text { (2016) } \\
{[29]}\end{array}$ & $\begin{array}{l}\text { 1. Uncover the motor skills of ASD children. } \\
\text { 2. Data collection techniques using tests and } \\
\text { measurements. }\end{array}$ & $\begin{array}{l}\text { 1. Conditions of the COVID-19 } \\
\text { Pandemic. } \\
\text { 2. Data collection followed health } \\
\text { protocols. } \\
\text { 3. The use of a newer instrument, the } \\
\text { TGMD-2. }\end{array}$ \\
\hline
\end{tabular}

Limitations of the new research study include: 1) The researcher cannot fully control the physical activity of the research participants; 2) Researchers cannot fully control the emotional condition of ASD children, and; 3) The number of participants is obtained from a less extensive population.

\subsection{Participant}

Participants in this study were ASD children with a total of 25 children aged 8-12 years $(M=10.02$; SD 1.27). Participants were selected by random sampling technique in various areas who were willing and granted permission to measure their gross motor skills [26]. All activities are carried out in the participants' home environment. The conditions for the place must be fulfilled by the participants, namely around the house (if there is a hall that is large enough) and the indoor field. Treatment group participants underwent an exercise program with guidance from researchers while observing the health protocols that were established during the COVID-19 pandemic.

\subsection{Instruments}

The research instrument was the Test of Gross Motor Development-2 (TGMD-2) to measure the gross motor skills of ASD children [30].

\subsection{Data Collection Technique}

The data collection technique is by testing the gross motor skills of ASD children using TGMD-2, which is divided into two subtests, namely locomotor and object control. Locomotor, locomotor subtest measures the following gross motor skills that require coordinated body movements with fluids when the child moves in one direction or another [30], among them:

1. Run - the ability to progress steadily by jumping so that both feet leave the ground in an instant with each step.

2. Gallop - the ability to perform fast and natural three-tap galts.

3. Hop- the ability to jump the minimum distance on each leg

4. Leap - the ability to perform all skills related to jumping over an object.

5. Horizontal jump-the ability to perform a horizontal jump from a standing position.

6. Slide-the ability to slide in a straight line from one point to another.

Then Object Control, Control object subtest measures gross motor skills that demonstrate efficient throwing and catching movements [30], in between:

1. Striking a stationary ball - the ability to hit a stationary ball with a plastic stick.

2. Stationary dribble - the ability to dribble at least four times with your dominant hand before catching the ball with both hands without moving your feet.

3. Catch - the ability to catch a plastic ball that has been thrown at a low swing.

4. Kick - the ability to kick the ball still with the preferred foot.

5. Overhand throw - the ability to throw the ball at a point on the wall with the preferred hand.

6. Underhand roll - the ability to roll the ball between two cones with the preferred hand.

To facilitate and support the implementation, a task card for ASD children is used [31], as in Figure 1 below: 


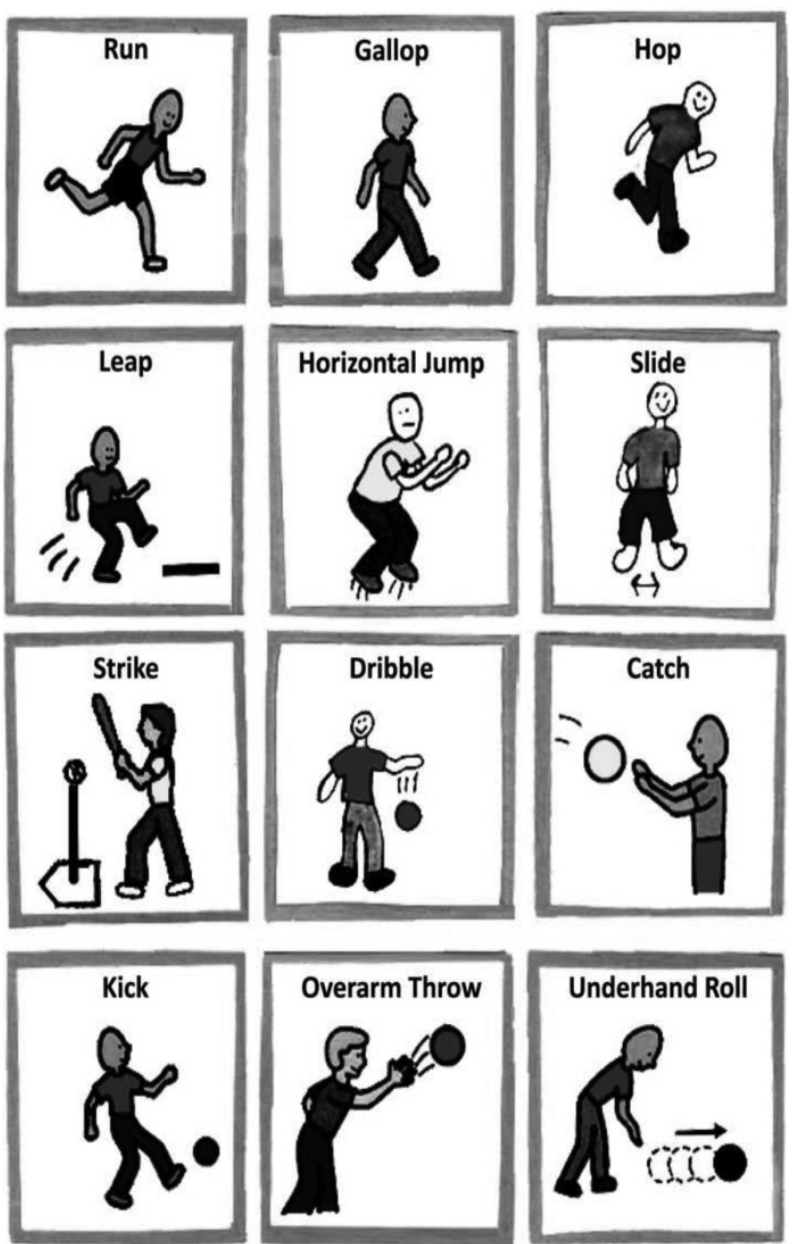

Figure 1. The pictorial task card used to facilitate the implementation and understanding of ASD children [29]

\subsection{Data Analysis}

Data analysis in this study is descriptive analysis [26]. Descriptive analysis reveals descriptive data about frequency distribution and locomotor categorization, object control, and total gross motor skills of ASD children. The results of the gross motor ability scores of ASD children are categorized based on 7 categories as shown in Table 2.

Table 2. Classification of the gross motor skills in ASD children

\begin{tabular}{ccc}
\hline No & $\begin{array}{c}\text { Average } \\
\text { Standard Score }\end{array}$ & Assessment \\
\hline 1 & $17-20$ & Very high \\
\hline 2 & $15-16$ & High \\
\hline 3 & $13-14$ & Above average \\
\hline 4 & $8-12$ & Average \\
\hline 5 & $6-7$ & Below average \\
\hline 6 & $4-5$ & Low \\
\hline 7 & $1-3$ & Very low \\
\hline
\end{tabular}

\section{Results}

\subsection{Results of Frequency Distribution of ASD Children's Gross Motor Data Frequency}

Description of data about students' gross motor skills consisted of locomotor and control objects. The results of the descriptive statistics for gross motor skills in ASD children group $(\mathrm{n}=25)$ can be seen in Table 3 .

Table 3. Statistics Descriptive of the gross motor skills in ASD children

\begin{tabular}{|c|c|c|}
\hline \multirow{2}{*}{ Skill } & \multicolumn{2}{|c|}{ Standard Score } \\
\hline & Mean & SD \\
\hline \multicolumn{3}{|c|}{ Locomotor } \\
\hline Run & 5.96 & 1.43 \\
\hline Gallop & 4.36 & 1.04 \\
\hline Hop & 3.12 & 0.93 \\
\hline Leap & 3.04 & 0.89 \\
\hline Horizontal jump & 4.24 & 1.09 \\
\hline Slide & 4.12 & 0.93 \\
\hline \multicolumn{3}{|c|}{ Object Control } \\
\hline Striking a stationary ball & 6.04 & 1.70 \\
\hline Stationary Dribble & 4.12 & 1.05 \\
\hline Catch & 4.04 & 1.06 \\
\hline Kick & 6.04 & 1.62 \\
\hline Overarm Throw & 3.04 & 0.98 \\
\hline Underhand Roll & 4.36 & 1.04 \\
\hline
\end{tabular}

\subsection{The Gross Motor Data Category of ASD Children was Reviewed from Locomotor}

The results of obtaining gross motoric data for ASD children were reviewed from Locomotor, then the average score for each ASD child was included in the category and can be seen in Table 4 below:

Table 4. The category of Gross Motoric Data for ASD children was reviewed by Locomotor

\begin{tabular}{ccccc}
\hline \multirow{2}{*}{ No } & $\begin{array}{c}\text { Average } \\
\text { Standard } \\
\text { Score }\end{array}$ & \multicolumn{2}{c}{ Frequency } & Absolute \\
\cline { 3 - 4 } & (f) & $\begin{array}{c}\text { Relatively } \\
(\%)\end{array}$ & Assessment \\
\hline 1 & $17-20$ & 0 & $0,00 \%$ & Very high \\
\hline 2 & $15-16$ & 0 & $0,00 \%$ & High \\
\hline 3 & $13-14$ & 0 & $0,00 \%$ & Above average \\
\hline 4 & $8-12$ & 0 & $0,00 \%$ & Average \\
\hline 5 & $6-7$ & 0 & $0,00 \%$ & Below average \\
\hline 6 & $4-5$ & 19 & $76,00 \%$ & Low \\
\hline 7 & $1-3$ & 6 & $24,00 \%$ & Very low \\
\hline & Total & 25 & $100 \%$ & \\
\hline
\end{tabular}


Based on table 3, the results show that 19 ASD children are in the average standard score of 4-5 in the low assessment category $(76.00 \%)$ and 6 ASD children are in the average standard score of 1-3 in the very low assessment category $(24,00 \%)$. Therefore, the majority of the gross motor data of ASD children in terms of locomotor data for ASD children were in the low category, namely 19 children or $76.00 \%$.

\subsection{ASD Children's Gross Motor Data Categories Are Viewed from the Object Control}

Table 5. Categories of Gross Motoric Data for ASD children in terms of locomotor motion

\begin{tabular}{|c|c|c|c|c|}
\hline \multirow[b]{2}{*}{ No } & \multirow{2}{*}{$\begin{array}{c}\text { Average } \\
\text { Standard } \\
\text { Score }\end{array}$} & \multicolumn{2}{|c|}{ Frequency } & \multirow[b]{2}{*}{ Assessmen } \\
\hline & & $\begin{array}{c}\text { Absolute } \\
\text { (Fa) }\end{array}$ & $\begin{array}{c}\text { Relatively } \\
(\%)\end{array}$ & \\
\hline 1 & $17-20$ & 0 & $0,00 \%$ & Very high \\
\hline 2 & $15-16$ & 0 & $0,00 \%$ & High \\
\hline 3 & $13-14$ & 0 & $0,00 \%$ & $\begin{array}{l}\text { Above } \\
\text { average }\end{array}$ \\
\hline 4 & $8-12$ & 0 & $0,00 \%$ & Average \\
\hline 5 & $6-7$ & 0 & $0,00 \%$ & $\begin{array}{c}\text { Below } \\
\text { average }\end{array}$ \\
\hline 6 & $4-5$ & 23 & $92,00 \%$ & Low \\
\hline \multirow[t]{2}{*}{7} & $1-3$ & 2 & $8,00 \%$ & Very low \\
\hline & Total & 25 & $100 \%$ & \\
\hline
\end{tabular}

The results of obtaining gross motoric data for ASD children were reviewed from the Object control, then the mean score for each ASD child was included in the category and can be seen in Table 5 .

Based on table 5, the results showed that 23 ASD children were in the average standard score of 4-5 in the low assessment category $(92.00 \%)$ and 6 ASD children were in the average standard score 1-3 included in the very low assessment category $(8,00 \%)$. Therefore, the majority of the gross motor data of ASD children in the object control category of ASD children were in the low category, namely 23 children or $92.00 \%$.

\subsection{Total Gross Motor Data Category for ASD Children}

The results of the total gross motoric data were obtained for ASD children, then the mean score for each ASD child is included in the category and can be seen in Table 5 below.

Based on table 6, the results show that 20 ASD children are in the average standard score of 4-5 (gross motor question $=70-79)$ in the low assessment category $(80.00 \%)$ and 5 ASD children are in the average standard score of $1-3$ (gross motor question $=<70$ ) is included in the very low assessment category $(20.00 \%)$. Therefore, the majority of the total gross motoric data for ASD children are in the low category, namely 20 children or $80.00 \%$.

Table 6. Total gross motor data categories of ASD children

\begin{tabular}{|c|c|c|c|c|c|}
\hline \multirow{2}{*}{ No } & \multirow{2}{*}{$\begin{array}{c}\text { Average } \\
\text { Standard Score }\end{array}$} & \multirow{2}{*}{ Gross Motor Quotient } & \multicolumn{2}{|c|}{ Frequency } & \multirow{2}{*}{ Assessment } \\
\hline & & & Absolute $(\mathrm{Fa})$ & Absolute (Fa) & \\
\hline 1 & $17-20$ & $>130$ & 0 & $0,00 \%$ & Very high \\
\hline 2 & $15-16$ & $121-130$ & 0 & $0,00 \%$ & High \\
\hline 3 & $13-14$ & $111-120$ & 0 & $0,00 \%$ & Above average \\
\hline 4 & $8-12$ & $90-110$ & 0 & $0,00 \%$ & Average \\
\hline 5 & $6-7$ & $80-89$ & 0 & $0,00 \%$ & Below average \\
\hline 6 & $4-5$ & $70-79$ & 20 & $80,00 \%$ & Low \\
\hline \multirow[t]{2}{*}{7} & $1-3$ & $<70$ & 5 & $20,00 \%$ & Very low \\
\hline & & Total & 25 & $100 \%$ & \\
\hline
\end{tabular}




\section{Discussion}

Locomotor motion is a movement by moving the body from one place to another "Breslin \& Pan. In TGMD-2, children's locomotor motion is measured by several variables, namely running, gallop, hop, leap, horizontal jump, and slide [32]. The test results illustrated that the majority of the gross motor data of ASD children in terms of locomotor data for ASD children were in the low category, namely 19 children or $76.00 \%$. There are several factors that influence the ability when the test is carried out, it can be due to factors in self, environment and also because of factors of movement experience. The data also show that during the COVID-19 pandemic, ASD children do not move and do activities that involve all the abilities that exist in their bodies so that they are less developed optimally.

The object of control is an assessment of manipulative motion involving a medium in the form of a ball and a bat [31]. The results showed that the majority of the gross motor data of ASD children in the object control category of ASD children were in the low category, namely 23 children or $92.00 \%$. ASD children have obstacles in behaving carefully before doing something and the duration of thinking is not long to avoid mistakes in the movement that have been done again. There are also ASD children who are in a hurry to take the test and also lack confidence in their abilities, causing a feeling of imitating the friend next to them.

Gross Motor Quotient is a child's ability to move that uses the muscles most part or all of the limbs [31]. The development of this ability is influenced by the cognitive abilities of the child. Gross motor skills in children are the basic movement skills of children which are the foundation for children in carrying out various movement activities. Gross motor skills are manipulative abilities that are developed when the child is in the middle and / or uses objects such as throwing, pushing, hitting, throwing, catching, reflecting and dribbling. The results obtained for the gross motor skills of the children stated that the total gross motoric data of ASD children were in the low category, namely 20 children or $80.00 \%$.

This illustrates that the overall ability of students is on average, in other words, the ability of students is in the middle but tends to be less. Students still need to hone their locomotor and manipulative skills more diligently. Through physical education learning at the school, however, several factors can also affect the performance of students when the test is carried out. Researchers found that this factor was a lack of confidence in the abilities of students themselves and the ability of students to respond to an order or the ability of students to think (intelligence).

Furthermore, it is important to know about the factors that determine the skill level, especially in ASD children. The factors that determine these skills are divided into 3 parts [33].

\section{Learning process factors}

In the case of motion learning, the learning process that must be created is that which is carried out based on the stages outlined by the learning theory which is believed to be true and is selected based on the value of its benefits.

\section{Personal factors}

This point is addressed to each individual who has physical, mental, emotional, and abilities that are different from other individuals. About 12 personal factors related to the achievement of skills, are: (a) sensory acuity, namely the individual's ability to recognize the appearance of stimuli accurately; (b) perception, namely the ability to make meaning out of a particular situation that is taking place; (c) intelligence, namely the ability to analyze and solve a problem and make decisions related to the appearance of motion; (d) physical size, namely the ideal level of body size needed to succeed in a particular sport; (e) past experiences, namely the breadth and quality of past experiences related to the current situation and task movements studied; (f) abilities, namely abilities, skills and knowledge that are developed adequately to complete the tasks and situations being studied at this time; (g) emotions, namely the ability to direct and control feelings appropriately before and during tasks; (h) motivation, namely the optimal level of encouragement that can master the skills learned; (i) attitude, that is, there is an interest in learning something and giving value to the activity that is being carried out; (j) other personality factors, the presence of extreme traits such as aggressiveness, need for affiliation, or other behaviors that can or cannot be used, depending on the situation; (k) gender, namely the influence of body composition, experience, cultural factors on the implementation of activities and desire for achievement; and (1) age, namely the effect of chronological age and maturity on readiness and ability to learn and perform certain tasks.

\section{Situational factors}

The factors that influence more are environmental factors, focused on the given task, the equipment used, and the surrounding conditions in which the learning takes place. Suggestions or interpretations for future research, namely by paying attention to the limitations of this study as well as the following:

1. Researchers provide control over the physical activity of ASD children as study participants;

2. Researchers provide control over the emotional condition of ASD children during the research program, and;

3. The number of participants involves the wider population;

4. Further research is recommended regarding exercise programs in improving gross motor skills of ASD children during, in and after the COVID-19 pandemic. 


\section{Conclusions}

The results of gross motor skills show that 20 ASD children are in the average standard score of 4-5 (gross motor question $=70-79$ ) in the low assessment category $(80.00 \%)$ and 5 ASD children are in the average standard score of $1-3$ ( gross motor question $=<70$ ) is included in the very low assessment category $(20.00 \%)$. Therefore, the majority of the total gross motoric data for ASD children are in the low category, namely 20 children or $80.00 \%$. This research contributes to the implementation of future research, namely the need for treatment to optimize Gross Motor skills in Children with Autism Spectrum Disorder during the COVID-19 Pandemic. The urgency for proper and measurable treatment and the limitations of this study are important things to pay attention to for further research.

\section{Acknowledgments}

The author would like to thank all those who supported this research.

\section{Conflict of Interest}

All authors state that there is no conflict of interest in this study.

\section{REFERENCES}

[1] ACSM, "Staying Active During the Coronavirus Pandemic," 2020. [Online]. Available:

https://www.acsm.org/read-research/newsroom/news-relea ses/news-detail/2020/03/16/staying-physically-active-durin g-covid-19-pandemic. [Accessed: 05-Jun-2020].

[2] P. Chen, L. Mao, G. P. Nassis, P. Harmer, B. E. Ainsworth, and $\mathrm{F}$. Li, "Coronavirus disease (COVID-19): The need to maintain regular physical activity while taking precautions," J. Sport Heal. Sci., vol. 9, no. 2, pp. 103-104, 2020.

[3] S. J. Stratton, "COVID-19: Not a Simple Public Health Emergency," Prehosp. Disaster Med., vol. 35, no. 2, pp. 119-119, 2020.

[4] J. Wu and P. Zha, "Preventive, Mitigating, and Treatment Strategies for COVID-19," SSRN, vol. 2020, no. February 25 , pp. $1-38,2020$.

[5] Z. Ahmadinejad, N. Alijani, S. Mansori, and V. Ziaee, "Common Sports-Related Infections: A Review on Clinical Pictures, Management, and Time to Return to Sports," vol. 5, no. 1, pp. 1-9, 2014.

[6] P. Purwanto, R. Lumintuarso, and E. Burhaein, "Impact of Running Techniques through the Sprint Ability in Athletes during the COVID-19 Pandemic," Int. J. Hum. Mov. Sport. Sci., vol. 9, no. 5, 2021.
[7] R. J. Simpson et al., "Can exercise affect immune function to increase susceptibility to infection?," Exerc. Immunol. Rev., vol. 26, no. 1, pp. 8-22, 2020.

[8] WHO, Global action plan on physical activity 2018-2030: More active people for a healthier world. Switzerland: World Health Organization, 2018.

[9] WHO, "Be Active during COVID-19," 2020. [Online]. Available:

https://www.who.int/news-room/q-a-detail/be-active-durin g-covid-19. [Accessed: 05-Jun-2020].

[10] WHO, "Physical activity: Overview," 2020. [Online]. Available:

https://www.who.int/health-topics/physical-activity\#tab=ta b_1. [Accessed: 12-Dec-2020].

[11] E. Burhaein, "Aktivitas Fisik Olahraga untuk Pertumbuhan dan Perkembangan Siswa SD," Indones. J. Prim. Educ., vol. 1, no. 1, pp. 51-58, 2017.

[12] E. Burhaein, B. K. Ibrahim, and R. Pavlovic, "The Relationship of Limb Muscle Power, Balance, and Coordination with Instep Shooting Ability: A Correlation Study in Under-18 Football Athletes," Int. J. Hum. Mov. Sport. Sci., vol. 8, no. 5, pp. 265-270, 2020. DOI: 10.13189/saj.2020.080515.

[13] E. Burhaein, "Aktivitas Permainan Tradisional Berbasis Neurosainslearning Sebagai Pendidikan Karakter Bagi Anak Tunalaras," J. Sport. J. Penelit. Pembelajaran, vol. 3, no. 1, p. $55,2017$.

[14] I. A. D. Pramantik and E. Burhaein, "A Floor Time Approach to Improve Learning Outcomes of the Body Roll to the Side in Adaptive Physical Education Learning: Classroom Action Research Study on Two Cerebral Palsy Students," Int. J. Disabil. Sport. Heal. Sci., vol. 2, no. 2, pp. 45-53, 2019.

[15] I. D. Purnomo, T. Tomoliyus, and E. Burhaein, "Development of Learning Activities Playing a Ball on a Goal To Improve Manipulative Skills For Lower Class Students," Proc. 1st Int. Conf. Sci. Technol. an Internet Things, 2019.

[16] D. T. P. Phytanza and E. Burhaein, "The Effects of Tenure, Teacher Certification, and Work Motivation on Special Needs Teacher Performance," Univers. J. Educ. Res., vol. 8, no. 9 , pp. 4348-4356, 2020.

[17] E. Burhaein, B. Tarigan, and D. T. P. Phytanza, "The experience and understanding of the K-13 curriculum implementation of Indonesian teachers of Adapted Physical Education (APE)," Int. Sport. Stud., vol. 42, no. e, pp. 2942, 2020.

[18] E. Burhaein, D. T. P. Phytanza, and N. Demirci, "The development and validation of a revised Friendship Activity Scale and Adjective Checklist for use in the Indonesian Unified Sports program," Int. Sport. Stud., vol. 42, no. e, pp. 18-28, 2020.

[19] D. T. P. Phytanza and E. Burhaein, "Aquatic activities as play therapy children autism spectrum disorder," Int. J. Disabil. Sport. Heal. Sci., vol. 2, no. 2, pp. 64-71, 2019.

[20] Y. M. Putra, S. Purwanto, and E. Burhaein, "Effect of Limb Muscle Power Training with Leaps on Athlete's Speed 
during the COVID-19 Pandemic," Int. J. Hum. Mov. Sport. Sci., vol. 9, no. 3, pp. 461-465, 2021. DOI: 10.13189/saj.2021.090310.

[21] F. Mustofa, M. Mansur, and E. Burhaein, "Differences in the effect of learning methods massed practice throwing and distributed distributed practice on learning outcomes skills for the accuracy of top softball," J. Sport Sci. Res., vol. 4, no. 2, pp. 213-222, 2019.

[22] E. Burhaein, "Bagaimana Pendidikan Jasmani Adaptif di Era New Normal," in Bunga Rampai Strategi, Proses, Evaluasi, dan Model Pembelajaran Pendidikan Jasmani, Olahraga, dan Kesehatan (PJOK) pada Era Pandemi Covid-19, Surabaya: UNESA University Press, 2020.

[23] E. Burhaein, "Pembelajaran dalam Pandemi COVID-19: Mengapa Pendidikan Jasmani Adaptif Penting untuk Siswa Disabilitas di Sekolah Luar Biasa," in Disrupsi Strategi Pembelajaran Olahraga: Serta Tantangan dalam Menghadapi New Normal selama masapandemi Covid-19, Tulungagung: Akademia Pustaka, 2020, pp. 187-196.

[24] E. Burhaein, "Aktifitas Fisik, Pendidikan Jasmani Adaptif, dan COVID-19," in Akselerasi Berpikir Ekstraordinari Merdeka Belajar Pendidikan Jasmani dan Olahraga era Pandemi COVID-19, 1st ed., Tulungagung: Akademia Pustaka, 2021.

[25] E. Burhaein, N. Demirci, C. C. V. Lourenço, Z. Németh, and J. H. Saunders, "Coping with the COVID-19 Pandemic: the role of Physical Activity: An international position statement," Int. Sport. Stud., vol. 43, no. 1, 2021.

[26] J. R. Fraenkel, N. E. Wallen, and H. H. Hyun, How to design and evaluate research in education. New York: Mc Graw Hill, 2012.

[27] B. Provost and B. R. Lopez, "Levels of Gross and Fine Motor Development in Young Children with Autism Spectrum Disorder," Phys. Occup. Ther. Pediatr., vol. 27, no. 3, pp. 21-36, 2007.

[28] T. Liu, M. Hamilton, L. Davis, and S. ElGarhy, "Gross Motor Performance by Children with Autism Spectrum Disorder and Typically Developing Children on TGMD-2," J. Child Adolesc. Behav., vol. 2, no. 1, pp. 2-5, 2014.

[29] H. D. Pusponegoro et al., "Gross Motor Profile and Its Association with Socialization Skills in Children with Autism Spectrum Disorders," Pediatr. Neonatol., vol. 57, no. 6, pp. 501-507, 2016.

[30] D. A. Ulrich, Test of Gross Motor Development, 2nd ed. United States of America: pro-ed an international publisher, 2000 .

[31] C. M. Breslin and M. E. Rudisill, "The effect of visual supports on performance of the TGMD-2 for children with autism spectrum disorder," Adapt. Phys. Act. Q., vol. 28, no. 4, pp. 342-353, 2011.

[32] C. M. Breslin, J. R. Morton, and M. E. Rudisill, "Implementing a Physical Activity Curriculum into the School Day: Helping Early Childhood Teachers Meet the Challenge," Early Child. Educ. J., vol. 35, no. 1, pp. 429437, 2007.

[33] M. W. Metzler, Instructional models in physical education, 3rd Ed. New York: Routledge, 2017. 